This is a preprint of a foreword accepted for publication by IGI Global. This extract has been taken from the author's original manuscript and has not been edited. The definitive version of this piece may be found in Cases on research support services in academic libraries (pp. xv-xvii), IGI, Hershey, PA, ISBN 9781799845461, which can be purchased from https://www.igi-global.com.

\title{
Foreword
}

Academic libraries have traditionally served the dual purpose of supporting the teaching and research of their parent institutions, but the balance between the two core missions has shifted over time. In the 1990s developments in information and communication technologies transformed the higher education environment by juxtaposing access to networked electronic resources with use of onsite printed materials, which led to the significant expansion of information skills provision to help students navigate the complex hybrid library and information landscape. Paradoxically, the progressive switch from print to e-journals resulted in an apparent contraction of the library research contribution as many researchers stopped visiting periodicals collections and started relying on online services, with scientists and engineers often claiming they no longer used or needed the library as they failed to appreciate the role of librarians in enabling the convenient access to journal literature they now enjoyed. The success of the information literacy movement also fuelled an emerging perception that the library was primarily concerned with supporting teaching and learning.

A decade later the pendulum began to swing back in the other direction as new social, technological, economic and political forces combined to drive radical change in scholarly communications, scientific research, performance measurement and policy mandates. Developments in networked data-driven computationally-intensive collection-based discovery (e-science), the evolution of humanities computing into digital/computational humanities, promotion of interdisciplinary and transdisciplinary research to solve global problems, growth in scholarly use of social media and social networking, proliferation of new 'alternative' methods of impact assessment (altmetrics), but above all the overarching move towards open products and open processes in research and higher education have given libraries huge opportunities to reassert and redefine their roles across the scholarly knowledge cycle. The open movement and particularly the widespread mandating of openness by research funding bodies across the globe have put libraries and librarians back at the centre of scholarly activity and made researchers much more dependent on library support, expertise and co-operation to get things done.

The virtual invisibility of the electronic library and networked access to resources has been replaced with new high-visibility services and facilities, including digital scholarship centres and visualisation studios where researchers can get help and advice on state-of-the art technologies and tools. The emergence of digital open social scholarship as mainstream practice has extended library roles beyond repository management and regulatory compliance to scholarly publishing and policy formulation, as well as systems integration and software development. Libraries are taking on activities and jobs formerly the preserve of commercial publishers, university presses, research offices and technology services as both valued partners and sole traders. As the go-to people for emergent practices in scholarly communication, they are also assuming responsibility for advising researchers on data management plans (DMPs), managing budgets for article processing charges (APCs), negotiating rights for text and data mining (TDM), assisting faculty with author IDs and researcher networking/profiling systems, and raising awareness among researchers, students and administrators of strengths and weaknesses of alternative research analytics. 
Library support for student research and student publishing is another growth area in response to adoption of inquiry-based learning pedagogies and the identification of undergraduate research as a high-impact educational practice. Librarians are thus fulfilling roles as educators, consultants, producers, curators and evaluators of content, but across an ever widening portfolio of activities that has repositioned them as key workers and major players in the 21st century research environment. The library literature reflects this shift of interest, which is evident in the numerous surveys, case studies and edited collections published on data curation, digital scholarship, impact metrics, open practices, research support, rights literacy and scholarly publishing in the past five years. The Association of Research Libraries (ARL) has issued relevant titles in its SPEC Kits series; journals including Library Trends, Program and New Review of Academic Librarianship have published themed issues on such subjects; and leading professional publishers like ACRL, ALA and Facet have produced edited collections, introductory guides and substantial handbooks, all underlining how research support has now become the signature service for academic libraries.

The collection of cases in this book augments this literature by providing a snapshot of the current state of research support in a variety of academic libraries around the world, including contributions representing leading-edge practice at large research universities as well as studies from much smaller institutions that demonstrate the imperative of tailoring services to local contexts. With contributors from 12 countries spanning five continents, the volume offers a range of perspectives seldom found in a body of literature that tends to be dominated by the United States, United Kingdom and Australia, and to focus unduly on larger institutions. The diversity of institutions featured here provides confirmation that size isn't everything. Despite the disparities in resourcing, these cases illustrate several common themes that characterise effective library support for research in a fast-moving landscape: notably, the vital role played by librarians in educating and training researchers on new policies, practices, systems and technologies; the key requirement to work alongside researchers on developing customised and personalised support in novel situations where ready-made solutions don't exist; and above all the critical importance of forging strong relationships with researchers and other stakeholders that build trust as the foundation for new service models predicated on collaboration and partnership.

Sheila Corrall

Great Malvern, UK

\section{Author bio}

Sheila Corrall worked in public and national libraries before moving into higher education where she directed library, information and technology services at three UK universities. In 2004 she became Professor of Librarianship and Information Management at the University of Sheffield, where she served as head of the Information School and chaired the Information Literacy Network. In 2012 she moved to the University of Pittsburgh in the USA as chair of the Library and Information Science program and was involved in developing Digital Scholarship Services in the university library via an innovative research-practice partnership with the iSchool. Sheila has served on the committees and boards of national and international organisations, conferences and journals, and won many awards for her work including the 2003 International Information Industries Lifetime Achievement Award for outstanding contribution to the development of the information profession. Her professional mission is to advance information literacy, scholarly communication and reflective practice in information work and to improve public understanding of library work. Sheila officially retired in 2019 and now divides her time between research, writing and outdoor pursuits in the Malvern Hills and North Wales. 